\title{
STATE OF DIGITIZATION OF LIBRARY RESOURCES IN THE UNIVERSITY OF ILORIN LIBRARY, NIGERIA
}

\author{
Mr. George Osas Eromosele \\ University Library, University of Ilorin, Nigeria \\ $+2348036897391$ \\ eromosele.og@unilorin.edu.ng \\ Mrs. Olabisi Fadeke Adesina \\ University Library, University of Ilorin, Nigeria \\ $+2348160602278$ \\ osina@unilorin.edu.ng
}




\section{Abstract}

The study investigated the state of digitization of library resources in the University of Ilorin Library, Nigeria intending to make the resources available online in its institutional repository. The literature on the state of digitization of library resources in academic libraries worldwide is rich and elaborate in developed countries but there is a dearth of study on the state of digitization of library resources in Nigerian academic libraries. This current study, therefore, attempts to add to the body of knowledge by bridging the yawning gap observed in the literature. To achieve this set objective, the University of Ilorin) was selected. The University of Ilorin is governmentowned in Nigeria. The questionnaire, relevant literature and personal observation constitute the major instruments for data collection. The questionnaire was collected, coded and analyzed. The Statistical Package for the Social Sciences (SPSS) was used for the analysis. Descriptive statistics such as frequency and percentages were also used to analyze each research question. The study found out that the University of Ilorin Library is making efforts in digitizing its local contents for easy access, preservation and to improve on digital contents availability for their online users on certain subjects and resources. However, provisions are not made for the digitization of certain materials which could be of immense benefits to their online users. The low scale digitization of its resources is hindering access to some of their intellectual outputs on its institutional repository. Recommendations were made that more conscious effort should be made to digitize more of relevant library materials and the various useful intellectual properties of the institution so that user can gain access to a wider range of resources. Digitization policies should be formulated and implementation should be hastened. Users' education/digital literacy programs, as well as conscious training programs on ICT skills and competencies for university libraries' staff in Nigeria, should be introduced.

Keywords: Academic libraries, digitization, institutional repository, open access, University of Ilorin Library 


\section{Introduction}

Libraries around the world have adopted many advanced technologies to develop its service quality (Pandey and Misra, 2014). As a result, libraries and librarians have been charged with the responsibility of embracing and inculcating the use of these technologies in library services and processes (Nneji, 2018). This has led to libraries and allied institutions launching projects designed to digitize their collections in response to the global information exchange and for wider outreach. However, developing countries like Nigeria has embraced this laudable initiative by embarking on the digitization of library resources (Jagboro, Omotayo, and Aboyade, 2012). Digitization is one of the important aspects of current global information trends fits into library and information service for effective and efficient information dissemination, preservation of information resources and facilitating the integration of library services into the learning process of an academic institution (Oni, Abu and Ekeniyere, 2018). It is a powerful way to expand access to collections and enables their wide use for research, education, and other purposes (Baro, Oyeniran and Ateboh, 2013).

According to the SAA Glossary (Society of American Archivists, 2016), digitization is "the process of transforming analogue material into binary electronic (digital) form, especially for storage and use in a computer." In other words, digitization starts with the transformation of the analogue format of a resource to a digital format. For instance, the digitization of a document usually generates an image of words, which are then transformed into digital data through Optical Character This is based on the fact that without an electronic version of the library information resources, open access of library resources will be difficult to establish. It will also challenge the relative value given to paper originals of rare materials as digital holdings increase. Special collections will need to justify their unique value through a deeper understanding of their holdings and an extension of their scope (Hirtle and Peter, 2002).

In information systems, digitization usually refers to the conversion of printed text or images (photographs, illustrations, maps, etc.,) into binary signals using some kind of scanning device that enables the result to be displayed on a computer screen". Scanning devices which could be used in digitization include Computer systems; scanners which can be flatbed, handheld, or robust scanning machines like SMA 2, Book Scanners such as BookDrive Pro ATIZ Scanner, Kirtas, Digital cameras etc.; CD or DVD writer; Printer; and the materials to be digitized (Jagboro, Omotayo, and Aboyade, 2012). 
With advances in information communication technologies, academic libraries are now in a position to offer digitization services beyond university communities. By mobilizing digitization service available to off-campus communities, university libraries can reposition themselves as responsive and relevant in the face of a changing digital services landscape (Tharani, 2012). The rapid deployment of information and communication technologies to library processes, especially in the current 'Information Age', has led to the emergence of institutional repositories which are facilitating cooperation and collaboration, resource sharing, bibliographic control, information access and information dissemination of digitized materials (Dadzie and Walt, 2015). The digital materials to be digitized are usually of two types, one that is produced in analogue format (e.g. Printed books, manuscripts, etc.) and then converted to digital form. The other one is "born digital" means originally produced in machine-readable digital form (e.g. ebooks, e-journals, online databases, digital photographs, websites, multimedia etc.) and needs no digital conversion (Pandey and Misra, 2014). It is easier to work with born-digital information materials. They do not have to undergo complete digitization process.

Baro, Oyeniran, and Ateboh (2013), acknowledges that digitization is a powerful way to expand access to collections and enables their wide use for research, education, and other purposes. Digitization is the service provided to manage all collections of information, with associated services, where the information is stored in digital formats and accessible over a network. Likewise, digitization service such as scanning retrospective information materials, including rare, fragile, and often unique original items makes possible the availability of digitized intellectual contents online to be used freely for research purpose. When digitization service is beyond universities communities, it can help to advance scholarship and learning by ensuring consistent discovery of hidden collections (Tharani, 2012). Digitization service in a university makes intellectual resources generated by such institution electronically available in digital format to researchers via institutional repositories (Igwe, 2014). It also makes the availability of intellectual materials electronically possible (Ogbomo and Muokebe, 2015). Digital service will facilitate preservation and access to scholarly contents (Tharani and Karim, 2012).

There are a lot of digitization service initiatives ongoing in African countries which preserve and provide access to local content on the Wide Area Network (WAN) (Igwesi, 2010). Given the initiative, some universities such as University of Ilorin (UNILORIN), Covenant University (CU), University of Lagos (UNILAG) on and on have embraced this laudable project and the 
digitization service is now available and operational (though not in full fledge), which has since made some of their local contents somewhat visible on the web (Igwesi, 2010; Christopher, Chriatain and Happiness, 2015). However, it is based on this solid ground that this study strives to investigate the state of digitization of library resources in the University of Ilorin Library, Nigeria because of making the resources available on their online institutional repository.

\section{Statement of the Problem}

The state of digitization of library resources in a university library is crucial. It determines the extent to which a user can gain access to the intellectual outputs from such institution on their online repository. The resource from an online institutional repository is usually unique because they are mostly the intellectual properties of the providing institution which are hard to come by unless they make it available on an online platform. In recent years, academic libraries have started adopting technologies by taking local content digitization as an alternative solution to introduce free access to scholarly research, as well as the dissemination and preservation of digital documents as a response to the current digital age. Various efforts are being made by some universities in Nigeria to engaging in digitization of library resources such as scanning retrospective information materials, including rare, fragile, and often unique original items to make them visible on the web.

However, preliminary investigation revealed that some libraries in Nigeria engaged in digitization project on a low scale, thereby limiting user's access to their resources and thereby discouraging the open-access initiative. These problems may be as a result of the inherent challenges of digitization in Nigeria or the perceived benefits of digitization service among many others. These observations necessitate the study to fathom and appropriate measures taken to ameliorate the situation. As a result, this research study is set out to investigate the state of digitization of library resources in the University of Ilorin Library, Nigeria as a case study.

\section{Objectives}

The broad objective of this study is to investigate the state of digitization of library resources in the University of Ilorin Library, Nigeria. The specific objectives of this study are to:

- find out the various digitization services available

- find out the extent of digitization of library resources 
- factors responsible for the non-digitization of certain information materials

Based on this research objective, the following question is answered in this study:

RQ1. What are the various available digitization services?

RQ2. What is the extent of digitization of the library resources?

RQ3. What are the factors responsible for the non-digitization of certain information materials?

\section{Literature Review}

In today digital age, academic libraries are going digital. In congruence to the foregoing (Rafiq, Ameen and Jabeen, 2017) buttressed that academic libraries around the world are involved in various digitization services. The role of academic libraries has gradually changed from mere repositories of knowledge to "knowledge commons," where users access information in digital formats from remote servers (Duderstadt, 2009). Academic libraries are the major and most developed segment of libraries and are very much engaged in digitizing books, journals, newspapers, artefacts, art, music, theses and dissertations and other historical documents, as well as images of international and cultural interest and making them available on institutional repositories. Institutional repositories make free access to different types of information electronically possible (Ogbomo and Muokebe, 2015).

Renowned university libraries of the world have participated in the large-scale digitization initiatives, such as Google Book Search, Open Content Alliance, Microsoft Live Search Books Publisher Program and Million Book Project (Rafiq and Ameen, 2017). Through digitization, traditional library materials in the form of books, papers, manuscripts, documents, etc. are converted into electronic formats. Images (such as photographs or maps) are converted into digital representations using some type of scanning device so that they can be displayed and manipulated on a screen (Pandey and Misra, 2014). Digitization is a new approach in the dissemination of research findings in many developed countries. Unfortunately, Nigerian universities have not properly positioned themselves in the use of this method in the global dissemination of their research findings. This could be attributed to poor digitization exercise in digitizing library resources for open access (Ezema, 2011). 
The Institute of Museum and Library Services in the USA conducted a nationwide survey in 2002 and repeated it in 2006 to examine the status of technology and digitization in the nation's museums and libraries. The 2006 study revealed that academic libraries tend to agree most strongly that lack of staff time, lack of funds and other pressing priorities were the strongest hindrances to their digitization activities. Academic libraries in Nigeria universities are not left out in this trend of digitization (Nwabueze and Urhiewhu, 2015). Ezeani and Ezema (2011) in their study of Nigerian academic libraries revealed that the most nagging problem in the digitization is attracting the required skills for troubleshooting of equipment such as computer systems, scanners among others. Supporting this view, Ilesanmi (2013) noted that personnel involved in the digitization services do not fully possess the required digitization skills and as a result of the inadequate skills in library digital service project by librarians, it then requires that training and retraining from time to time be organized for digitizing librarians to meet with the requirement of their responsibility to effectively provide information to clienteles via institutional repositories.

In corroborating the above studies, Alhaji (2007) had earlier evaluated the status of digitization in 30 Nigerian university libraries intending to identify the status, progress, prospects and challenges to digitize library materials. The major obstacles for digitization in the Nigerian university libraries included lack of funds, lack of appropriate facilities, lack of skilled manpower, lack of institutional policy and lack of constant electricity supply. Iwhiwhu and Eyekpegha (2009) identified the problems influencing the effective library digitization projects in Nigerian university libraries as lack of policy and implementation, funding, epileptic power supply, unskilled staff for ICT applications, high cost of purchasing equipment, network fluctuations, lack of maintenance culture, space inadequacy, environmental disasters and lack of internet connectivity. These peculiar problems have affected the state of digitization and the availability of some library resources in some Nigeria academic libraries.

However, the availability of extensive digitalized library resources can facilitate access and increase the usage of the resources by users (Nwabueze and Urhiewhu, 2015). Through digitization, library information resources and the various intellectual output from emanating from faculties can be archived and made available electronically. Furthermore, the resources can then be made accessible on online institutional repositories. Rosenberg (2005) stated that 
digitized information resources are services frequently available over the Internet so that users can remotely access the resource electronically. This services are available in electronic format and could only be accessible on the web or through institutional intranet access. Rosenberg further stated that as libraries embrace the digital environment, their most crucial role is not that of providing e-resources, but of establishing services that facilitate access to the available information. According to Fabunmi, Paris and Fabunmi (2006), library digitization has become part of the work of libraries and librarian must make a relentless effort in making some selected library resources electronically available to users.

Based on the fore-cited literature, it could be inferred that the researched studies on digitization had focused on the various efforts on the digitization of library resources and the challenges faced with digitization especially in Nigeria. This current study attempts to add to the body of knowledge by bridging the yearning gap observed in the literature by focusing the study on a single academic library. The study focuses on ascertaining the state of digitization of library resources in the University of Ilorin Library, Nigeria. This is because the extent of the digitization project will determine how much users can gain access to the intellectual outputs on their online institutional repository. As a way forward, the digitization of the intellectual properties of the Nigerian universities, polytechnics, research institutes, colleges of technology, colleges of agriculture, colleges of education, etc., will significantly contribute to the achievement of open access of scholarly materials.

\section{Methodology}

The study adopted a survey research design. The study employed scientific, systematic methods and procedures to collect, analyze and present data for the study. The study was conducted at the University of Ilorin, North-central geopolitical zones of Nigeria. The study sample comprised of twenty-two (22) Academic Librarians from the University of Ilorin. The selection of academic librarians for this study is based on the premise that they are professional and in a better position to provide accurate information on the state of digitization of their library resources. This is also because all academic librarians from this institution are responsible for the information needs of the faculty members and their departments.

The selection of the University of Ilorin Library for the study is based on the fact that it will follow the trend of digitization of information resources because they are better equipped with 
digitization facilities. The total population sampling technique was used to examine the entire population of the respondents and the justification for using this sampling method is because all the librarians were involved in some form of activities in their various unit that contributes to the digitization of their library resources. The questionnaire and personal observation constitute the major instruments for data collection. Thereafter, the questionnaire was collected, coded and analyzed. The Statistical Package for the Social Sciences (SPSS) was used for the analysis. Descriptive statistics such as frequency and percentages were also used to analyze each research question.

\section{Results and Discussion}

The respondents in whom the questionnaire was administered totalled 22 academic librarians. In the University of Ilorin Library, twenty-two (22) copies of the questionnaire were administered to the Academic Librarians and fifteen (15) copies were retrieved. The copies of the questionnaire retrieved represented a return rate of $68.2 \%$ of the total questionnaire administered. The study findings are presented under the following sub-sections, in the same manner, the research questions were phrased.

Table 1: Various available digitization services

\begin{tabular}{|l|l|l|l|l|}
\hline & \multicolumn{3}{|l|}{ University of Ilorin Library } \\
\cline { 2 - 5 } & \multicolumn{2}{|l|}{ Available } & Not Available \\
\hline $\begin{array}{l}\text { Digitization } \\
\text { Services }\end{array}$ & F & F & $\%$ \\
\hline $\begin{array}{l}\text { Digitization of } \\
\text { original materials }\end{array}$ & 15 & 100 & 0 & 0 \\
\hline $\begin{array}{l}\text { Digitization of } \\
\text { rare materials } \\
\text { (special collection } \\
\text { materials) }\end{array}$ & 0 & 0 & 15 & 100 \\
\hline $\begin{array}{l}\text { Digitization of } \\
\text { fragile materials }\end{array}$ & 0 & 0 & 15 & 100 \\
\hline $\begin{array}{l}\text { Digitization of } \\
\text { unique items in the } \\
\text { library }\end{array}$ & 15 & 100 & 0 & 0 \\
\hline $\begin{array}{l}\text { Digitization from } \\
\text { microfilm contents }\end{array}$ & 0 & 0 & 15 & 100 \\
\hline Large format & 15 & 100 & 0 & 0 \\
\hline
\end{tabular}




\begin{tabular}{|l|l|l|l|l|}
\hline $\begin{array}{l}\text { scanning and } \\
\text { image stitching }\end{array}$ & & & & \\
\hline $\begin{array}{l}\text { Secure storage and } \\
\text { handling of } \\
\text { original materials }\end{array}$ & 11 & 73.3 & 4 & 26.7 \\
\hline $\begin{array}{l}\text { Long-term } \\
\text { preservation }\end{array}$ & 15 & 100 & 0 & 0 \\
\hline
\end{tabular}

From table 1 above, the respondents pointed out the various available digitization services. It was found that the University of Ilorin Library does no currently engaged in the digitization of rare materials, digitization of fragile materials and the digitization from microfilm contents. The return rate as not available was are 15(100\%), 15(100\%) and 15(100\%) respectively. Generally, it implies that the resources cannot be accessible online from this library even when the materials are available.

Table 2: Extent of digitization of library resources

\begin{tabular}{|l|l|l|l|l|l|l|l|l|}
\hline & \multicolumn{2}{|l|}{ VGE } & \multicolumn{2}{l|}{ GE } & \multicolumn{2}{l|}{ LE } & \multicolumn{2}{l|}{ NAA } \\
\hline Resources & F & \% & F & \% & F & \% & F & \% \\
\hline $\begin{array}{l}\text { Theses and } \\
\text { Dissertatio } \\
\text { n }\end{array}$ & 8 & 53.3 & 7 & 46.7 & - & - & - & - \\
\hline $\begin{array}{l}\text { Staff } \\
\text { Publication } \\
\text { s }\end{array}$ & 15 & 100 & - & - & - & - & - & - \\
\hline $\begin{array}{l}\text { Seminar } \\
\text { papers }\end{array}$ & - & - & - & - & 3 & 20 & 12 & 80 \\
\hline $\begin{array}{l}\text { Conference } \\
\text { proceeding } \\
\text { s }\end{array}$ & - & - & - & - & - & - & 15 & 100 \\
\hline $\begin{array}{l}\text { Post-prints } \\
\text { Local } \\
\text { Newspaper } \\
\text { s }\end{array}$ & - & - & - & - & - & - & 15 & 100 \\
\hline $\begin{array}{l}\text { Technical } \\
\text { reports }\end{array}$ & - & - & - & - & - & - & 15 & 100 \\
\hline $\begin{array}{l}\text { Gray } \\
\text { literature }\end{array}$ & - & - & - & - & 2 & 13.3 & 13 & 86.7 \\
\hline $\begin{array}{l}\text { Past } \\
\text { questions }\end{array}$ & - & - & - & - & - & - & 15 & 100 \\
\hline $\begin{array}{l}\text { Governmen } \\
\text { t }\end{array}$ & - & - & 5 & 33.3 & - & - & 10 & 66.7 \\
\hline
\end{tabular}




\begin{tabular}{|l|l|l|l|l|l|l|l|l|}
\hline $\begin{array}{l}\text { Publication } \\
\text { s }\end{array}$ & & & & & & & & \\
\hline $\begin{array}{l}\text { Graphic } \\
\text { materials }\end{array}$ & - & - & - & - & - & - & 15 & 100 \\
\hline $\begin{array}{l}\text { Inaugural } \\
\text { lectures }\end{array}$ & - & - & - & - & 13 & 88.1 & 2 & 13.3 \\
\hline
\end{tabular}

Key: VGE $=$ Very Great Extent, GE $=$ Great Extent, $\mathrm{LE}=$ Less Extent and NAA $=$ Not At All

The result of the analysis from Table 2 shows that staff publications with a frequency rate of 15 (100\%) were heavily digitized on a very large extent. The digitization of Theses and Dissertation was at a frequency rate of $8(53.3 \%)$ on very large extent and $7(46.7 \%)$ on a large extent respectively. These infer that the digitization of the resource is available almost averagely on a large extent but there is room to double their efforts to make it available on a very larger extent. The respondents' response on government publications with a frequency rate of 5(33.3\%) on a large extent is poor when compared to $10(66.7 \%)$ response rate of not at all. The inference from this result shows that the resource is poorly digitalized and the awareness among the academic librarians of the provision of the service within the University of Ilorin Library is poor.

However, the analysis results show that the digitization of seminar papers, local newspapers, grey literature, inaugural lectures are available on a less extent. Meanwhile, the digitization of conference proceedings, post-prints, technical reports, past questions, graphic materials are not at all in existence. The deduction from the analysis shows that the University of the Ilorin Library is engaging in digitization of its resources in a limited proportion and that it needs to improve on their efforts to expand their services and capture more resources to be digitized for the benefit of their online institutional repository users.

Table 3: Factors responsible for the non-digitization of certain information materials

\begin{tabular}{|c|c|c|c|c|c|c|c|c|c|}
\hline \multirow[t]{3}{*}{ S/N } & \multirow[t]{3}{*}{ Factors } & \multicolumn{8}{|c|}{ University of Ilorin } \\
\hline & & \multicolumn{2}{|c|}{$\mathbf{S A}$} & \multicolumn{2}{|c|}{$\overline{\mathbf{A}}$} & \multicolumn{2}{|c|}{ D } & \multicolumn{2}{|c|}{ SD } \\
\hline & & $\mathbf{F}$ & $\%$ & $\mathbf{F}$ & $\%$ & $\mathbf{F}$ & $\%$ & $\mathbf{F}$ & $\%$ \\
\hline 1 & $\begin{array}{l}\text { High cost of purchasing } \\
\text { robust scanners }\end{array}$ & - & - & - & - & - & - & 15 & 100 \\
\hline 2 & $\begin{array}{lll}\text { Low } & \text { skilled } & \text { (ICT) }\end{array}$ & - & - & 12 & 80 & 3 & 20 & - & - \\
\hline
\end{tabular}




\begin{tabular}{|l|l|l|l|l|l|l|l|l|l|}
\hline & manpower & & & & & & & & \\
\hline 3 & $\begin{array}{l}\text { Use of unsuitable } \\
\text { Application Software } \\
\text { for digitization }\end{array}$ & - & - & 2 & 13.3 & 1 & 6.7 & 12 & 80 \\
\hline 4 & $\begin{array}{l}\text { Lack of policy and } \\
\text { standards }\end{array}$ & 1 & 6.7 & 2 & 13.3 & 5 & 33.3 & 7 & 46.7 \\
\hline 5 & $\begin{array}{l}\text { Copyright infringement } \\
\text { challenges }\end{array}$ & 5 & 33.3 & 8 & 53.3 & 2 & 13.3 & - & - \\
\hline 6 & $\begin{array}{l}\text { Low perceived } \\
\text { usefulness }\end{array}$ & 3 & 20 & 7 & 46.7 & 2 & 13.3 & 3 & 20 \\
\hline 7 & Poor ICT infrastructure & 1 & 6.7 & 1 & 6.7 & 2 & 13.3 & 11 & 73.3 \\
\hline 8 & $\begin{array}{l}\text { Lack of proper } \\
\text { planning } \\
\text { digitization project }\end{array}$ & - & - & 6.7 & 2 & 13.3 & 13 & 86.7 \\
\hline 9 & $\begin{array}{l}\text { Poor Internet } \\
\text { connectivity }\end{array}$ & 1 & 6.7 & 3 & 20 & 8 & 53.3 & 3 & 20 \\
\hline 10 & $\begin{array}{l}\text { Unwillingness to key } \\
\text { into full open access } \\
\text { initiative }\end{array}$ & 2 & 13.3 & 5 & 33.3 & 5 & 33.3 & 3 & 20 \\
\hline 11 & $\begin{array}{l}\text { Poor funding } \\
12\end{array}$ & 4 & 20 & 5 & 33.3 & 6 & 40 & 1 & 6.7 \\
\hline Irregular power supply & 2 & 13.3 & 3 & 20 & 6 & 40 & 4 & 20 \\
\hline
\end{tabular}

Key: SA = Strongly Agree, A = Agree, $\mathrm{D}=$ Disagree, SA = Strongly Disagree

The analysis results in Table 3 shows that among the major factors responsible for the nondigitization of certain information materials are inadequate manpower with a response frequency rate of $12(80 \%)$, copyright infringement challenges with a response rate of 5(33.3\%) of strongly agree and $8(53.3 \%)$ of agree, low perceived usefulness with a response rate of $3(20 \%)$ of strongly agree and 7(46.7\%) of agree, and poor funding with a response rate of 4(20\%) of strongly agree and $5(33.3 \%)$ of agreed. 
Of the response of copyright infringement; low perceived usefulness and poor funding on the average scale of the agreement shows that these factors have devastatingly affected the state of digitization of information resources in the University of Ilorin Library.

\section{Conclusion}

The outcomes of the study are quite revealing. Digitization of library resources leads to so many laudable benefits in making more hardcopy information, materials electronically transformed into softcopy for onward electronic archiving on online institutional repositories for users' access. The result of the analysis has shown that there is ongoing digitization of library resources in the University of Ilorin Library. However, the library is yet to expand its digitization project to capture a wider range of information resource. Invariably, it means that there are limitations to the extent to which a user can access scholarly contents on their online institutional repository. The findings show that the University of Ilorin is yet to commence the digitization of conference proceedings, post-prints, technical reports, past questions, and graphic materials. The nondigitization of this material shows that users cannot have remote access to the resources on their institutional repositories as earlier stated. The study concludes that the digitization of more library resources and its availability on an online platform such an institutional repository will aid easier access to intellectual outputs of the host institutions for research purpose.

\section{Recommendations}

Based on the findings of this study, the following recommendations are suggested:

1. The University of Ilorin library should make a more conscious effort to institutionalize the digitization of library information, materials and make it available online for users to access.

2. The library should engage in digitizing a wide range of resources without leaving some out. As this will lead to an increase in the availability of resources electronically when it is made available in online platforms such as institutional repository.

3. The University of Ilorin Management should increase funding to the digitization of library resources project. There should be more funding on procurement of modern digitization equipment such as scanning machines; high-end servers, high capacity computers, and digital cameras. This will help to ensure effective digital service operations. 
4. Library management should properly and systematically tackle the issue of insufficient manpower by making a proper case to the University's Management on the need to employ more skilled personnel to advance the project.

5. More so, digitization policies and standards on copyright infringement should be formulated and as such implementation should be hastened.

6. Users' education/digital literacy programs, as well as conscious training programs on ICT skills and competencies for the Library's staff, lecturers and students in the University, should be introduced to boost the perceived usefulness of the service among the University Community.

\section{References}

Alhaji, I.U. (2007). Digitization of past question papers, dissertations and theses: a case study of 30 Nigerian university libraries. International Information \& Library Review, Vol. 39 Nos 3/4, pp. 228-246.

Baro, E.E., Oyeniran, K.G., and Ateboh, (2013). Digitization projects in university libraries in Nigeria: the journey so far. Library Hi Tech News Number 9 2013, pp. 21-26, q Emerald Group Publishing Limited, 0741-9058, DOI 10.1108/LHTN-09-2013-0049.

Christopher, N., Chriatain, B., and Happiness, M. (2015). Managing a Sustainable Institutional Repository: The Covenant University Experience. Retrieved from the web on the 28th of April, 2019.

Dadzie, P.S. and Walt, T. (2015). Digitizing university libraries in Ghana: how technology is facilitating access to digital content and services. Unisa University of South Africa. Volume 33 | Numbe"r 3 | 2015 pp. 95-114.

Duderstadt, J.J. (2009), Possible futures for the research library in the 21st century. Journal of Library Administration, Vol. 49 No. 3, pp. 217-225.

Ezeani, C.N. and Ezema, I.J. (2011). Digitizing institutional research output of University of Nigeria, Nsukka. Library Philosophy and Practice, available at: www.webpages.uidaho.edu/,mbolin/ezeaniezema. Pdf. 
Ezeani, C.N. and Ezema, I.J. (2011). Digitizing institutional research output of University of Nigeria, Nsukka. Library Philosophy and Practice, available at: www.webpages.uidaho.edu/mbolin/ezeaniezema. Pdf.

Ezema, I.J. (2011). Building open access institutional repositories for global visibility of Nigerian scholarly publication. Challenges, strategies and scholarly Implications. Library Review Vol. 60 No. 6, 2011 pp. 473-485q Emerald Group Publishing Limited 0024-2535 DOI 10.1108/00242531111147198.

Fabunmi, B.A., Paris, M. \& Fabunmi, M (2006). Digitization of library resources: Challenges \& and implications for policy and planning. International Journal of African \& African American Studies, 5(2), 23-36.

Hirtle, Peter B. (2002). The Impact of Digitization on Special Collections in Libraries. Permission is granted for nonprofit educational and library duplication and distribution, including but not limited to reserves and coursepacks made by nonprofit or for-profit copyshops.

Igwe, K.N. (2014). Open Access Repositories in Academic and Research Institutions for the Realization of Nigeria's Vision 20: 2020. International Journal of Information Science and Management, Vol. 12, No. 1, 2014, 33-46.

Igwesi, U. (2010). Status of Digitization of Federal University Libraries in South-eastern zone of Nigeria. Available on the web:

http://www.unn.edu.ng/publications/files/images/UZOAMAKA\%20IGWESI.pdf. Retrieved on $27^{\text {th }}$ April, 2019.

Ilesanmi, T. C. (2013). Digitization of Journal Collections in Libraries: A Case Study of Kenneth Dike Library, University of Ibadan, Nigeria. Journal of Interlibrary Loan, Document Delivery \& Electronic Reserve, 23:35-45, 2013 Published with license by Taylor \& Francis ISSN: 1072-303X print / 1540-3572 online DOI: 10.1080/1072303X.2013.794185.

Institute of Museum and Library Services (IMLS) (2002) and (2006). Status of Technology and Digitization in the Nation's Museums and Libraries, IMLS, Washington, DC. 
Iwhiwhu, B.E. and Eyekpegha, E.O. (2009). Digitization of Nigerian university libraries: from technology challenge to effective information delivery. The Electronic Library, Vol. 27 No. 3, pp. 529-536.

Jagboro, K.O., Omotayo, B.O. and Aboyade, W.A. (2012). Digitization of Library Collection in Developing Countries: The Hezekiah Oluwasanmi Library Experience. Library Philosophy and Practice http://digitalcommons.unl.edu/libphilprac/ISSN 1522-0222.

Jagboro, K.O., Omotayo, B.O., and Aboyade, W.A. (2012). Digitization of Library Collection in Developing Countries: The Hezekiah Oluwasanmi Library Experience. Library Philosophy and Practice (e-journal. Libraries at University of Nebraska-Lincoln. http://digitalcommons.unl.edu/libphilprac 11-19-2012.

Mat, S.Y. and Kolej, A.M.N. (2005). Digitization and sustainability of local collection: an observation of digitization activities among universities libraries. World Library and Information Congress: 71th IFLA General Conference and Council "Libraries - A Voyage of Discovery", Oslo. Nigeria: the journey so far. Library Hi Tech News Number 9 2013, pp. 21-26, q Emerald Group Publishing Limited, 0741-9058, DOI 10.1108/LHTN-092013-0049.

Nneji, K.O. (2018). Digitization of academic library resources: A casestudy of Donal E. U. Ekong Library. Library Philosophy and Practice (e-journal, Summer 8-21-2018. Avaialable at: http://digitalcommons.unl.edu/libphilprac.

Nwabueze, A.U., and Urhiewhu, O., (2015). Availability and Use of Digital Information Resources by Undergraduates of Universities in Delta and Edo States, Nigeria. International Journal of Digital Library Services ISSN:2250-1142 (Online), ISSN 2349302X. www.ijodls.in.

Ogbomo, E.F and Muokebe, B. (2015). Institutional Repositories, as Emerging Initiative in Nigerian University Libraries. Information and Knowledge Management www.iiste.org.

Oni, O., Abu, L., and Ekeniyere, I.A., (2018). Prospects and Challenges of Digitization of Academic Libraries Resources for Effective Services Delivery in Universities in Edo State. International Research: Journal of Library \& Information Science | Vol.8 No.2, Jun., 2018. 
Pandey, P. and Misra, R. (2014). Digitization of Library Materials in Academic Libraries: Issues and Challenges. Journal of Industrial and Intelligent Information Vol. 2, No. 2, June 2014. doi: 10.12720/jiii.2.2.136-141.

Rafiq, M., Ameen, K., and Ameen, k. (2017). Barriers to digitization in university libraries of Pakistan: a developing country's perspective. The Electronic Library, https://doi.org/10.1108/EL-01-2017-0012 Permanent link to this document: https://doi.org/10.1108/EL-01-2017-0012.

Rosenberg, D. (2005). Towards the digital library: Findings of an investigation to establish the current status of university libraries in Africa. UK: INASP. Accessed from http://www.inasp.info/uploaded/documents/digital-libr-final-format-web.pdf."

Tharani, K. (2012). Collections Digitization Framework: A Service-oriented Approach to Digitization in Academic Libraries. The Canadin Journal of Library and Information Practice and Research vol. 7, no. 2 (2012). 
